\title{
Cytopathological Dilemma of Anaplastic Sacral Chordoma with Radiological and Histological Corroboration
}

\author{
Radyolojik ve Histolojik Doğrulama ile Anaplastik Sakral Kordomanın \\ Sitopatolojik Tanısı
}

\author{
Arghya BANDYOPADHYAY, Bidyut Krishna GOSWAMI, Raghunath PRAMANIK, Kaushik MAJUMDAR, \\ Mimi GANGOPADHYAY
}

Department of Pathology, North Bengal Medical College, WEST BENGAL, INDIA

\begin{abstract}
Chordoma is a relatively rare locally invasive and potentially malignant tumor of fetal notochord origin, affecting the axial skeleton. Cytopathological diagnosis of chordoma is favored by the presence of characteristic physaliphorous cells, bearing abundant foamy cytoplasm dispersed in a myxoid matrix. Anaplastic chordoma or dedifferentiated chordoma, an even rarer variant, can cause a diagnostic confusion with chondrosarcoma from the cytopathological point of view, with similar chondromyxoid matrix and atypical cells. Hence, chordoma bearing anaplastic features needs to be identified and should be distinguished from chondrosarcoma on aspiration cytopathology. We present a case of anaplastic sacral chordoma in a man 59 years of age, causing extensive destruction of sacrum and invading the paravertebral tissues as evidenced by radiology. Fine needle aspiration cytopathology revealed few large pleomorphic hyperchromatic cells, admixed with characteristic physaliphorous cells and myxoid matrix. The cytopathological diagnosis has been confirmed by histopathology and immunohistochemistry. Since anaplastic chordoma bears an unfavorable prognosis, it should be suspected on preoperative aspiration cytopathology. Clinicoradiological correlation along with histopathological and immunohistochemical confirmation is necessary subsequently.
\end{abstract}

Key Words: Chordoma, Anaplasia, Fine needle aspiration, Cytology

\begin{abstract}
ÖZ
Kordoma, fetal notokord kökenli, orta hat iskelet yerleşimli, nispeten nadir, lokal invaziv ve malign davranışlı bir tümördür. Kordoma sitopatolojik tanısı, mikzoid matrikste geniş köpüklü sitoplazmalı tipik fizaliferöz hücrelerin görülmesi ile konabilir. Anaplastik veya dediferansiye kordoma daha nadir görülmektedir ve benzer kondromikzoid matriks ve atipik hücreler içerdikleri için sitopatolojik olarak kondrosarkom ile karışabilir. Bu nedenle, anaplastik özellikler gösteren kordomanın aspirasyon sitolojilerinde tanınması ve kondrosarkomdan ayırdedilmesi gerekir. Burada 59 yaşındaki bir olguda izlenen, radyolojik olarak paravertebral dokuları invaze eden ve sakrumu yıkıma uğratmış anaplastik sakral kordoma sunulmaktadır. İnce iğne aspirasyon sitolojisinde az sayıda pleomorfik ve hiperkromatik hücre ile karışık mikzoid matriks içinde fizaliferöz hücreler izlenmiştir. Sitopatolojik tanı, histopatoloji ve immünohistokimya ile doğrulanmıștır. Anaplastik kordoma kötü seyir gösterdiği için preoperatif aspirasyon sitolojisinde tanınmalıdır. Klinikoradyolojik korelasyon ve sonrasında histopatolojik ve immünohistokimyasal doğrulama gereklidir.
\end{abstract}

Anahtar Sözcükler: Kordoma, Anaplazi, İnce iğne aspirasyonu, Sitoloji

mono or multinucleated cells are present besides the typical cellular pattern in some cases of dedifferentiated chordoma or anaplastic chordoma $(2,3)$. Only a few case reports are available describing the cytopathology of such chordomas with anaplastic features (4).

We herein describe a case of sacral mass which was diagnosed as anaplastic chordoma on fine needle aspiration cytopathology (FNAC) and was later confirmed

Correspondence: Arghya BANDYOPADHYAY

Department of Pathology, North Bengal Medical College,

SUSHRUTANAGAR, DARJEELING, INDIA

E-mail: drarghyabanerjee@yahoo.com Phone: +919433389946 
by histopathology and immunohistochemistry. Such anaplastic chordomas need to be differentiated early from chondrosarcomas on preoperative aspiration cytopathology.

\section{CASE REPORT}

A man aged 59 years was admitted with a swelling in the lower back region for 9 months, constipation for 2 and half months and pain for 15 days. On clinical examination, there was a tender soft mass present in the sacrococcygeal region. On rectal examination, a soft mass was detected in presacral region approximately $10 \mathrm{~cm}$ in diameter, pushing the posterior rectal wall anteriorly. Motor and sensory function of both lower limbs and anal reflexes were all normal. Routine laboratory investigations were within

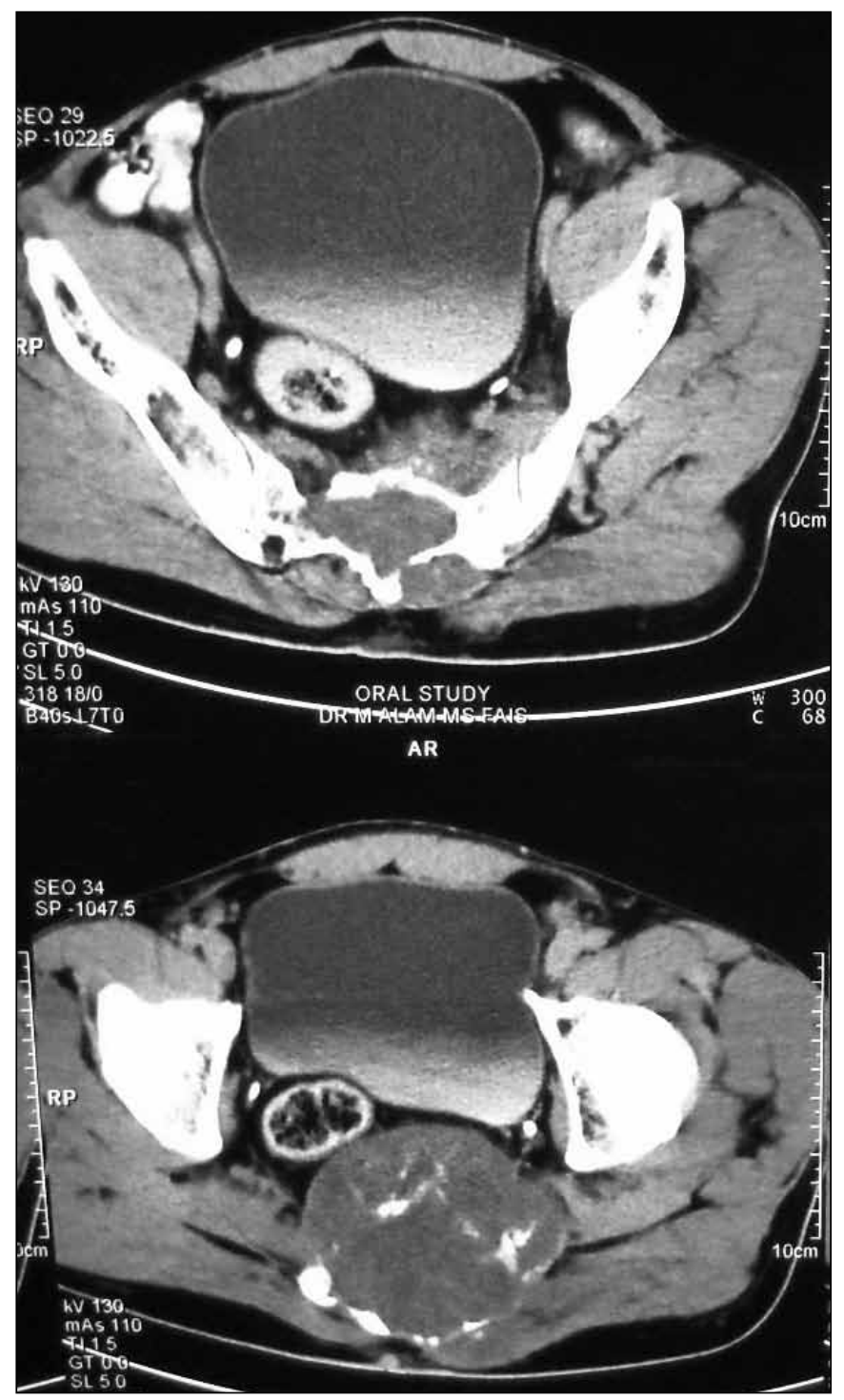

Figure 1: CT scan shows heterogeneously enhancing space occupying lesion, causing destruction of the distal sacrum and pushing the rectum anteriorly. normal limits. Computed Tomography (CT) Scan showed a heterogeneously enhancing space-occupying lesion of $8 \times 8.2 \mathrm{~cm}$ size, causing destruction of the distal sacrum, extending on the anterior aspect in the perirectal space and abutting on to the rectum (Figure 1). The rectal shape was deformed. Dorsally the mass was extending through the sacrum into the subcutaneous region. The paravertebral muscles on the left side were also involved.

FNAC from the mass yielded blood-stained mucoid material. The smears were highly cellular and composed of tumor cells medium to large in size with a rounded well demarcated cytoplasm and central nucleus. The cytoplasm was abundant and foamy to bubbly in appearance (classical physaliphorous cell) (Figure 2). Many binucleated cells and multinucleated giant cells were also seen (Figure 2, inset), along with few pleomorphic spindle cells. Some of the cells had prominent nucleoli. The cells were arranged in groups with abundant magenta colored stroma in the background encircling individual cells (Figure 3). Mitotic figures were not seen. The diagnosis of anaplastic chordoma was considered on the basis of clinical, radiological and predominantly, cytopathological findings.

An open excision biopsy was performed. Histopathology from the mass lesion showed a lobulated tumor separated

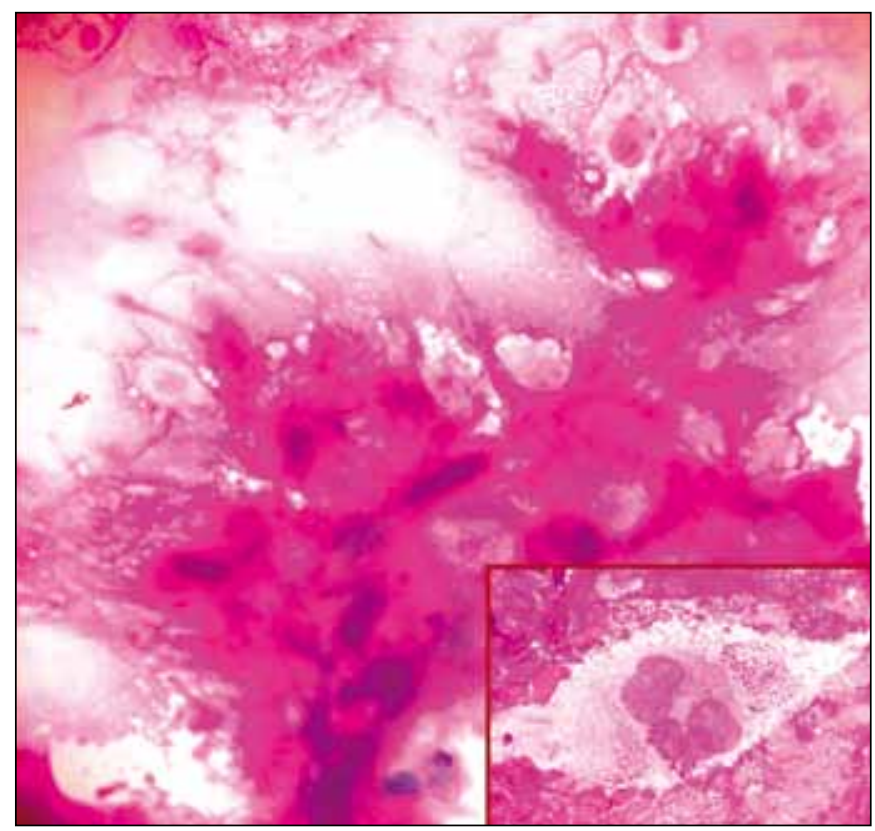

Figure 2: Cytopathology smear showing large mono or binucleated physaliphorous cells with vacuolated cytoplasm, centrally located nucleus and granular chromatin pattern in a deep magenta colored myxofibrillary background (Giemsa, x10). Inset: Bizarre multinucleated tumor giant cell with vacuolated cytoplasm (Giemsa, x40). 
by fibrous strands. The cells were arranged in sheets, lobules and cords, dispersed in abundant myxoid stroma. Typical physaliphorous cells were present, along with scattered highly pleomorphic cells with large bizarre nuclei (Figure 4).

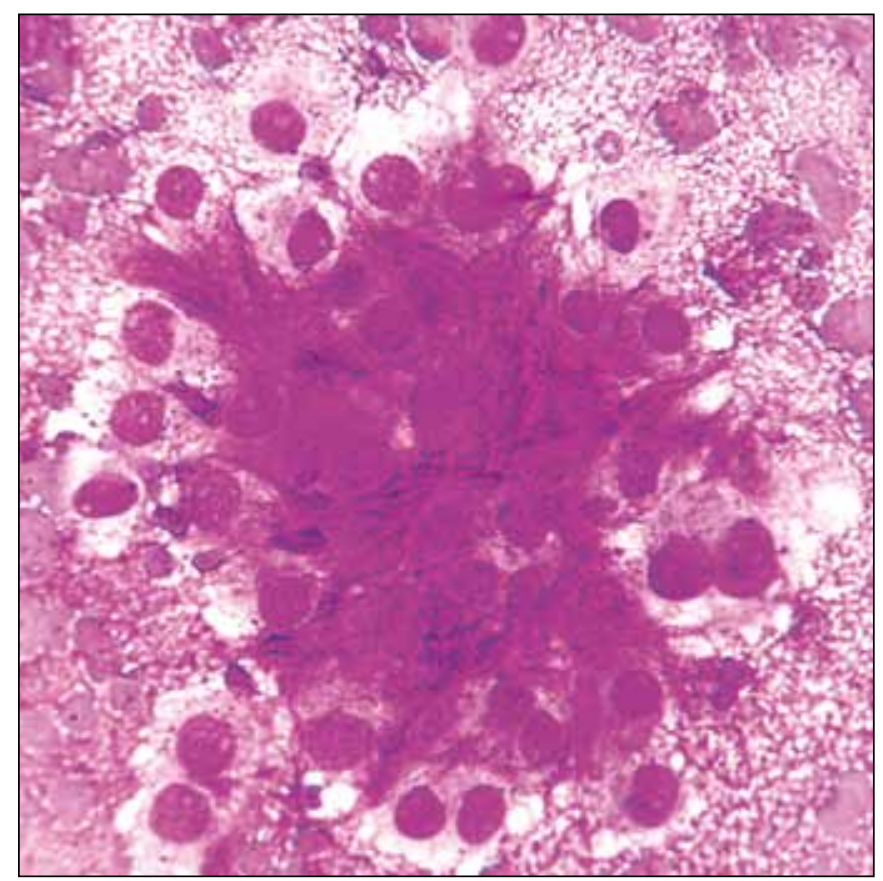

Figure 3: Cytopathology smear showing a network of myxofibrillary material encircling individual tumor cells with abundant pale bubbly cytoplasm and pleomorphic nuclei (Giemsa, x40).

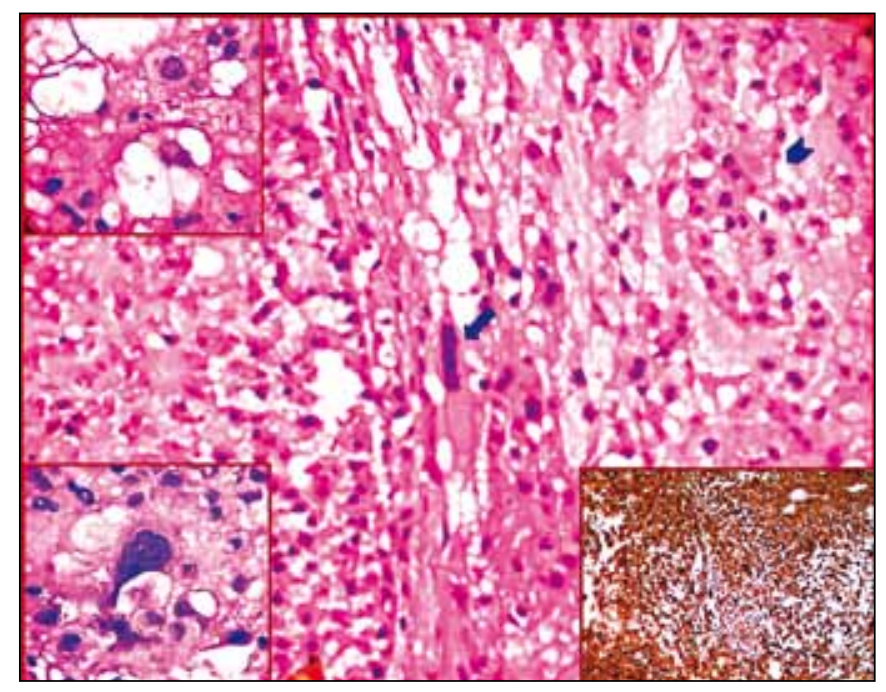

Figure 4: Anaplastic chordoma with the features of lobulation, myxoid matrix and vacuolated cells arranged in cords (arrow head), along with large anaplastic cells (arrow) (H\&E, x10). Insets: (Above left)-A typical physaliphorous cell (H\&E, $\mathrm{x} 40)$. (Below left)-An anaplastic tumor cell with large hyperchromatic nucleus and vacuolated cytoplasm ( $\mathrm{H} \& \mathrm{E}, \mathrm{x} 40)$. (Below right)The tumor cells are intensely positive for cytokeratin (x10).
Binucleated and multinucleated tumor giant cells were also seen. Mitosis was infrequent $(<2 / 10$ high power field). The tumor was locally infiltrative, invading the left paravertebral muscles. Left lateral resection margin was involved by the tumor. Immunohistochemistry (IHC) for pan-cytokeratin showed strong positivity. The histopathology and IHC hence confirmed our cytopathological diagnosis. The patient received radiation therapy of 6000 cGy over 5 weeks, and is now on regular follow-up with no recurrence at 8 months post surgery.

\section{DISCUSSION}

Chordoma is a distinct malignant neoplasm arising from the remnants of the notochord, occurring mostly in the 5th or 6th decade of life, most frequently in the sacral area (5). The cytopathological features classical of chordoma include dissociated and small groups of polygonal cells, along with presence of physaliphorous cells in a background of conspicuous extracellular myxoid matrix (4). In our case, we found an anaplastic component in the form of bi- and multinucleated cells, bizarre giant cells some bearing large pleomorphic nuclei as well as few pleomorphic spindle cells along with the typical features of chordoma. Rone et al first described anaplastic chordoma by FNAC (3). Nijhawan et al described anaplastic chordoma as presence of bizarre cells with profound multinucleation and presence of intranuclear inclusion (4). The presence of pleomorphic cells and/or spindle cells in chordoma has been variously named as anaplastic (3), sarcomatoid (6), and dedifferentiated (7). Dedifferentiated chordoma is a rare and aggressive variant of the conventional chordoma in which an area undergoes transformation to a high grade lesion and dictates overall survival (8).

Subsequent histopathological examination in our case showed the characteristic architecture of chordoma, bearing lobules and cords of cells embedded in a myxoid matrix. In addition to physaliphorous cells, the aggressive nature of cells seen in cytology smears was also confirmed in histopathology. Mitotic figures were absent in the aspiration cytology smears from the tumor. In a study by Crapanzano et al mitotic figures were rarely observed in cytology smears of chordoma (9). Ng et al reported a case of dedifferentiated or sarcomatoid sacral chordoma, where spindle and pleomorphic cells were mitotically inactive (6). Other than cytological features of dedifferentiation, adverse prognostic factors are represented by large tumor size, positive surgical margins, necrosis and high proliferative activity (10). In our case the tumor size was $8 \times 8.2 \mathrm{~cm}$, with invasion of paravertebral muscles and destruction of the sacrum, along with positive resection margins. However, necrosis 
was absent and assessment of proliferative activity was not possible in our setup although it would have been useful. Immunohistochemically the neoplastic cells are reactive for S 100 protein, cytokeratin and epithelial membrane antigen, but usually negative for carcinoembryonic antigen (3). In the present case, we have excluded adenocarcinoma by cytopathology and histopathological examination of the resected tumor. Strong positivity for cytokeratin in this case excluded the possibility of chondrosarcoma and other myxoid sarcomas.

The main differential diagnosis in our case was from a welldifferentiated chondrosarcoma. Other tumors that should be considered in differential diagnosis on cytopathology include metastatic clear cell carcinoma, especially renal cell carcinoma or mucin producing adenocarcinoma, myxoid liposarcoma and myxoid malignant fibrous histiocytoma $(\mathrm{MFH})(2,11)$. In low-grade chondrosarcoma, the aspiration cytology smears show cells in lacunae in a cartilaginous matrix, along with binucleation, multinucleation and few pleomorphic, hyperchromatic nuclear forms. The diagnosis of chordoma was preferred over chondrosarcoma in this patient as the physaliphorous cells were identified, and in a few areas the myxoid matrix was seen encircling the tumor cells individually (Figure 3 ). Abundant ground substance of chordoma may be inconspicuous in hematoxylin and eosin or Papanicolaou-stained smears and the epithelial like tumor cells may give a false impression of an epithelial neoplasm (11). Giemsa-stained smears of this case showed deep magenta colored myxofibrillary ground substance, that excludes the possibility of a clear cell adenocarcinoma (Figure 2). FNAC has proven to be a useful tool in the diagnosis of adult myxoid sarcomas (12). Myxoid liposarcoma show characteristic lipoblasts with scalloped nuclei and vacuolated cytoplasm along with a delicate branching capillary network against a myxoid background $(13,14)$. The myxoid variant of MFH displays a mixture of atypical spindle cells, pleomorphic histiocyte-like cells and multinucleated cells in an abundant myxoid background, often containing a curved vessel fragment $(15,16)$. These features were not present in our case.

To conclude, the cytomorphological features of chordoma allow accurate diagnosis by FNAC. Features associated with dedifferentiation or anaplasia include increasing pleomorphism, a prominent nucleolus, binucleation and presence of multinucleated bizarre giant cells. Recognition of these anaplastic features helps to expand the morphological spectrum of chordoma and differentiate from chondrosarcoma, clear cell adenocarcinoma or other myxoid sarcomas at the preoperative stage.

\section{REFERENCES}

1. Bohra M, Mogra N, Patni A, Sujnani S: Diagnostic aspiration cytology of sacral chordoma. J Cytol 2007, 24:60

2. Akerman M: Benign and Malignant Tumours of Bone. In Gray W, Mckee GT. (Eds): Diagnostic Cytopathology. 2nd ed., Edinburgh, Elsevier Churchill Livingstone, 2003, 924-925

3. Rone R, Ramzy I, Duncan D: Anaplastic sacrococcygeal chordoma. Fine needle aspiration cytologic findings and embryologic considerations. Acta Cytol 1986, 30:183-188

4. Nijhawan VS, Rajwanshi A, Das A, Jayaram N, Gupta SK: Fineneedle aspiration cytology of sacrococcygeal chordoma. Diagn Cytopathol 1989, 5:404-407

5. Lin O, Zakowski MF: Cytology of Soft Tissue, Bone and Skin. In Bibbo M, Wilbur D. (Eds): Comprehensive Cytopathology. 3rd ed., Philadelphia, Elsevier Saunders, 2008, 493-500

6. Ng WK, Tang V: Crush preparation findings of "sarcomatoid" chordoma of the sacrum: report of a case with histologic, immunohistochemical, and ultrastructural correlation. Diagn Cytopathol 2001, 25:406-410

7. Layfield LJ, Liu K, Dodd LG, Olatidoye BA: "Dedifferentiated" chordoma: a case report of the cytomorphologic findings on fineneedle aspiration. Diagn Cytopathol 1998, 19:378-381

8. Hanna SA, Tirabosco R, Amin A, Pollock RC, Skinner JA, Cannon SR, Saifuddin A, Briggs TW: Dedifferentiated chordoma: a report of four cases arising 'de novo'. J Bone Joint Surg Br 2008, 90:652-656

9. Crapanzano JP, Ali SZ, Ginsberg MS, Zakowski MF: Chordoma: a cytologic study with histologic and radiologic correlation. Cancer 2001, 93:40-51

10. Rosai J: Rosai and Ackerman's Surgical Pathology. 9th ed., St. Louis, Missouri, Elsevier Mosby, 2004, 2183-2185

11. Akerman M: Bone. In Orell SR, Sterrett GF, Whitaker D. (Eds): Fine Needle Aspiration Cytology. 4th ed., Edinburgh, Elsevier Churchill Livingstone, 2005, 441-442

12. Kilpatrick SE, Ward WG, Bos GD: The value of fine-needle aspiration biopsy in the differential diagnosis of adult myxoid sarcoma. Cancer 2000, 90:167-177

13. Akerman M, Rydholm A: Aspiration cytology of lipomatous tumors: a 10-year experience at an orthopedic oncology center. Diagn Cytopathol 1987, 3:295-302

14. Walaas L, Kindblom LG: Lipomatous tumors: a correlative cytologic and histologic study of 27 tumors examined by fine needle aspiration cytology. Hum Pathol 1985, 16:6-18

15. Walaas L, Angervall L, Hagmar B, Säve-Söderbergh J: A correlative cytologic and histologic study of malignant fibrous histiocytoma: an analysis of 40 cases examined by fine-needle aspiration cytology. Diagn Cytopathol 1986, 2:46-54

16. Merck C, Hagmar B: Myxofibrosarcoma: a correlative cytologic and histologic study of 13 cases examined by fine needle aspiration cytology. Acta Cytol 1980, 22:137-144 